\title{
SCIENTIFIC COMMUNICATION \\ Belostoma dilatatum (Dufour) (Hemiptera, Belostomatidae) hosting metacercariae of Stomylotrema vicarium Braun (Digenea, Stomylotrematidae) in southern Brazil ${ }^{1}$
}

\author{
Suzana B. Amato ${ }^{2} \&$ José F. R. Amato ${ }^{2}$ \\ ${ }^{1}$ Contribuição No 461 do Departamento de Zoologia, Universidade Federal do Rio Grande do Sul. \\ ${ }^{2}$ Departamento de Zoologia, Instituto de Biociências, Universidade Federal do Rio Grande do Sul, Porto Alegre, \\ Caixa Postal 15014, 91501-970 Porto Alegre, Rio Grande do Sul, Brasil.E-mail: sbamato@ufrgs.br; jfamato@terra.com.br
}

\begin{abstract}
Giant water bugs (aquatic Heteroptera), Belostoma dilatatum (Dufour, 1863), were collected in rice plantation water canals, in the Municipality of Eldorado do Sul, outskirts of Porto Alegre, State of Rio Grande do Sul, southern Brazil. Five specimens were dissected with the objective of finding metacercariae of digenetic trematodes. Four of them (80\%) were positive for metacercarial cysts of Stomylotrema vicarium Braun, 1901. The intensities of infection varied from 1 to 16 metacercariae per host (average 7.6). The cysts were whitish, translucent, and found loose among the viscera, in the abdominal and thoracic cavities. Belostoma dilatatum is a new host record for metacercarial cysts of stomylotrematid digenetic trematodes and this is the first time that aquatic hemipterans are recorded as second intermediate hosts of digenetic trematodes in Brazil.

KEY WORDS. Heteroptera; trematode; Neotropical; Rio Grande do Sul; South America.
\end{abstract}

RESUMO. Belostoma dilatatum (Dufour) (Hemiptera, Belostomatidae) hospedando metacercárias de Stomylotrema vicarium Braun (Digenea, Stomylotrematidae) na região Sul do Brasil. Baratas-d’água (heterópteros aquáticos), Belostoma dilatatum (Dufour, 1863), foram coletadas em canais ao lado de taipas e córregos em plantações de arroz, no Município de Eldorado do Sul, grande Porto Alegre, Estado do Rio Grande do Sul, região Sul do Brasil. Cinco espécimes foram examinados com o objetivo de detectar a presença de metacercárias de trematódeos digenéticos. Quatro deles (80\%) estavam positivos para cistos de metacercárias de Stomylotrema vicarium Braun, 1901. As intensidades de infecção variaram de 1 a 16 metacercárias por hospedeiro (média de 7,6). Os cistos eram esbranquiçados, translúcidos, e estavam soltos entre as vísceras, nas cavidades abdominal e torácica dos hemípteros. Belostoma dilatatum é um novo registro de hospedeiro para metacercárias de trematódeos digenéticos da família Stomylotrematidae, assim como este é o primeiro registro de hemípteros aquáticos servindo como segundo hospedeiro intermediário de trematódeos digenéticos no Brasil.

PALAVRAS CHAVE. América do Sul; Heteroptera; Neotropical; Rio Grande do Sul; trematódeo.

Belostomatid hemipterans (aquatic Heteroptera) have been recorded as hosts for ectocommensals and endohelminths in Argentina (Moretto 1978, Ostrowski de NúÑez 1978, dE Villalobos et al. 1998, Digiani 2002), India (Dhanumkumari \& Madhavi 1983, Shyamasundary \& Rao 1998), and Brazil (Vianna \& de Melo 2002, Аmato \& Amato 2005).

During a survey of aquatic hosts of temnocephalid epibionts belostomatid hemipterans were found to harbor metacercariae of stomylotrematid digenetic trematodes. The objective of the present paper is to report for the first time in Brazil the belostomatid hemipterans as the natural second intermediate hosts of Stomylotrema vicarium Braun, 1901, as well as to document, photographically, these metacercariae within the insect host.

Live metacercariae were obtained from hemipterans collected from rice plantation water canals $5 \mathrm{~km}$ West of Interstate Road BR-290, locality of Arrozeira, Municipality of Eldorado do Sul (30 01'36"S, 051 22'42”W), State of Rio Grande do Sul. Hemipterans were collected around June of 2003, as part of a larger study of epibionts of aquatic invertebrates. Insects were collected with dip nets and/or large sand sieves and transported live to the laboratory. Five specimens of Belostoma dilatatum (Dufour, 1863) were examined by removing the legs and the abdominal and thoracic sternites. Live metacercariae 

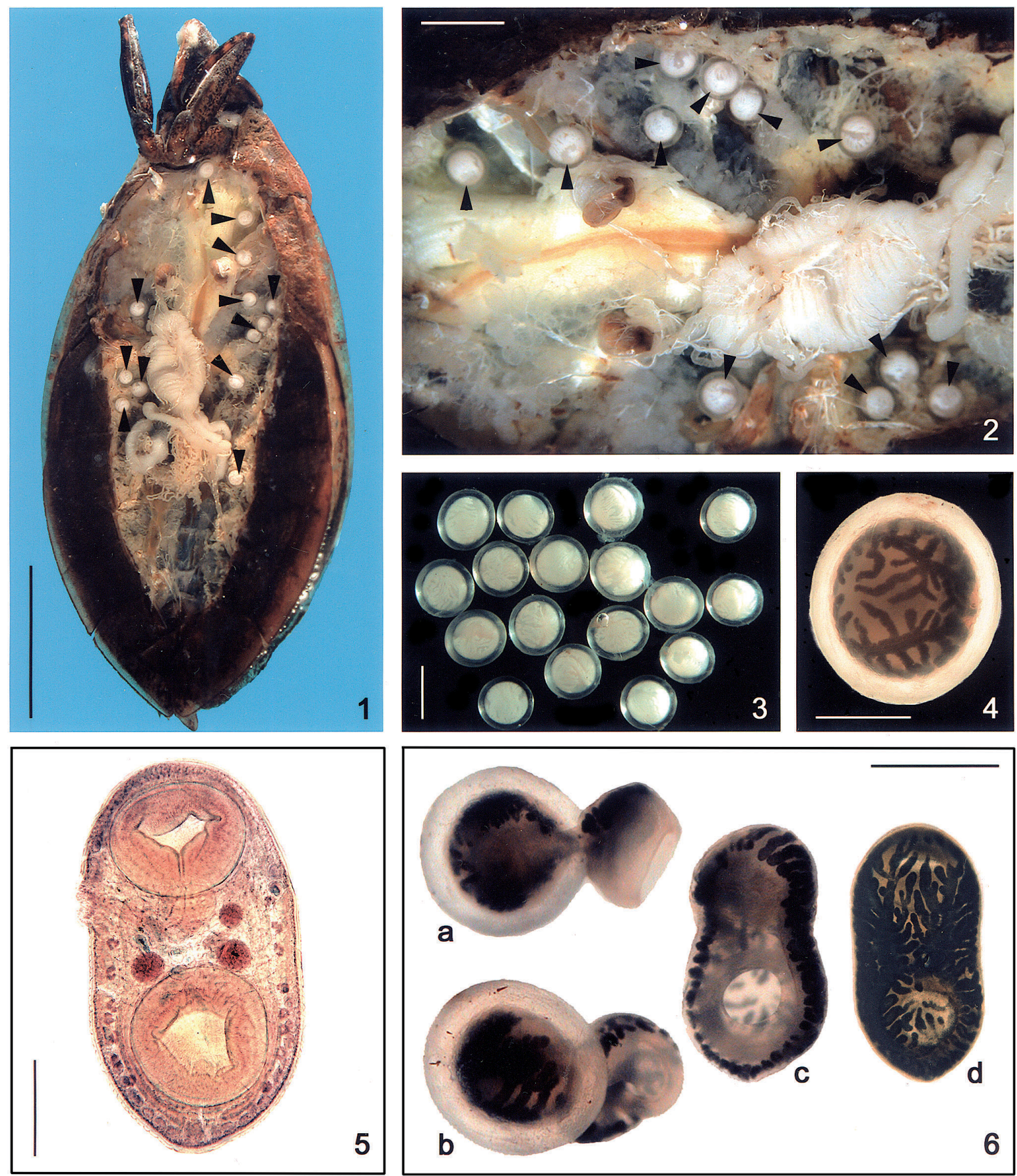

Figures 1-6. Belostoma dilatatum and the metacercariae of Stomylotrema vicarium: (1) adult hemipteran with part of the ventral abdomen and thoracic sternites, and the second and third pairs of legs removed, cysts are indicated by head arrows, bar = $10 \mathrm{~mm}$; (2) another specimen of $B$. dilatatum showing the original location of metacercarial cysts (head arrows), bar = $2 \mathrm{~mm}$; (3) live metacercariae removed from host, showing the thickness of the cyst wall, under special illumination, bar $=1 \mathrm{~mm}$; (4) live, encysted metacercaria, showing the thick cyst wall and excretory vesicle with the two main ducts and its lateral ramifications, bar $=500 \mu m$; (5) excysted metacercaria, fixed and stained, showing the primordial ovary, testes, vitellaria, and cirrus sac. Figures 6a-d. Live metacercariae of Stomylotrema vicarium: (ab) metacercaria in the process of leaving the cyst; (c) metacercaria after leaving the cyst (ventral view); (d) metacercaria after leaving the cyst (dorsal view), bar $=500 \mu \mathrm{m}$, for Figs $6 \mathrm{a}, \mathrm{b}, \mathrm{c}$, and $\mathrm{d}$.

Revista Brasileira de Zoologia 23 (1): 307-310, março 2006 
removed from the hosts were studied by puncturing the cyst wall and allowing their extrusion from the cysts. Larvae were killed/fixed with hot $\left(90^{\circ} \mathrm{C}\right)$ phosphate buffered $10 \%$ formalin or with cold A.F.A. (АмATO \& AMATO 2005), under minimal cover slip pressure; stained in Delafield's hematoxylin, and mounted in Canada balsam. Measurements are in micrometers unless otherwise indicated; range values are followed, within parentheses, by the averages and their standard deviation. Voucher specimens, mounted in toto, are deposited in the Coleção Helmintológica do Instituto Oswaldo Cruz (CHIOC), Rio de Janeiro, RJ, Brazil.

\section{Stomylotrema vicarium Braun, 1901 Figs $1-6$}

Description: Metacercarial cysts $(n=10)$. Whitish, translucent cysts found loose among viscera in the abdominal and thoracic cavities (Figs 1 and 2); diameter, including the cyst wall, 1026-1185 (1090, 48.8); diameter of encysted metacercariae 730-958 (872, 59.4); cyst wall thickness 64-119 (95.1, 15.0) (Figs 3 and 4).

Excysted, stained, mounted metacercariae $(n=6)$ (Fig. 5): body 1.57-1.73 mm (1.64 mm, 62.3) long, 775-1117 (862.6, 128.5) wide. Oral sucker $456-524$ (505.4, 39.2) long, 502-570 $(551,26.6)$ wide; pharynx 137-165 $(146.5,13.7)$ long, 174-211 $(198,13.8)$ wide; caeca long, reaching the area posterior to acetabulum. Testes 119-146 (131, 11.1) long, 183-211 (186) wide; cirrus pouch 293.1-393.8 $(368.1,43.2)$ long, 73.2-82.4 $(80.5,4.1)$ wide. Ovary 91.6-100.7 (99.1, 3.7) long, 100.7-109.9 (103.9, 4.9) wide. Acetabulum 524-661 (577.6, 55.2) long, 502-661 (577.6, 53.3) wide. Ratio of oral sucker to acetabulum diameter 1.01:1.

Host. Belostoma dilatatum (Dufour, 1863) (Hemiptera, Belostomatidae).

Sites of infection. Abdominal and thoracic cavities.

Locality. Rice plantation water canals $5 \mathrm{~km}$ West of Interstate Road BR-290, locality of Arrozeira, Municipality of Eldorado do Sul $\left(30^{\circ} 01^{\prime} 36^{\prime \prime}\right.$, $\left.051^{\circ} 22^{\prime} 42^{\prime \prime} \mathrm{W}\right)$, State of Rio Grande do Sul, Brazil.

Prevalence. $80 \%$.

Intensity of infections. 1-16.

Average intensity of infection. 7.6.

Deposited specimens. CHIOC \# 36.590a and b - mounted metacercariae.

Remarks. OstrowsKi De NúÑEz (1978) recorded the presence of stomylotrematids in the Province of Buenos Aires collecting the second intermediate host harboring the metacercariae and identified the species as $S$. vicarium through experimental infection of a 1-day-old chick, Gallus gallus (Linnaeus, 1758) and a lapwing, Vanellus chilensis (Molina, 1782), which were fed with metacercariae from a larval water beetle, Megadytes glauca Brullé, 1837 (Dytiscidae). Very young metacercariae still unencysted showing the stylet, as reported by that author, were not found in the present study. DigIANI (2002) reported the presence of metacercariae of Stomylotrema sp. in three species of giant water bugs of the genus Belostoma: Belostoma elegans (Mayr, 1871) and Belostoma oxyurum (Dufour, 1863) from the Province of Buenos Aires, and Belostoma foveolatum (Mayr, 1863) from the Province of Misiones.

Figure 3 of Ostrowski De NúÑEz (1978) shows one metacercaria removed from M. glauca, while figure 3 of Digiani (2002) and figure 5 (present report) show drawings and a photomicrograph, respectively, of excysted metacercariae removed from belostomatid hemipterans. The metacercariae from the coleopteran and from the hemipterans are quite similar, while the measurements of the cyst wall thickness as well as of their diameter also are in accordance. Cysts seen in situ (Figs 1-2) and removed from the body cavity (Figs 3 and 4) show the same thick wall and dense, whitish excretory vesicle reported by Digiani (2002).

Beltzer (1995), in the only study of the food habits of Guira guira Gmelin, 1783 known to date, indicated that belostomatid hemipterans were present among 39 taxonomic entities found in the proventriculus of 22 guira cuckoos examined during the four seasons of the year. This might explain why guira cuckoos are observed to fly over the canals from where the hemipterans have been collected and why the prevalence of these metacercariae is so high. Surprisingly, this is the first record for Brazil of belostomatids serving as second intermediate hosts of digenetic trematodes and specifically of metacercariae of any species of Stomylotrema.

\section{ACKNOWLEDGEMENTS}

The authors are indebted to Drs José R.I. Ribeiro and Jorge Luiz Nessimian, Universidade Federal do Rio de Janeiro, for identifying the belostomatid hemipterans; to Dr John Polhemus, Colorado Entomological Institute, Englewood, Co, USA, for kindly providing the correct publication dates for the species of naucorids mentioned in the text; to Dr Maria Helena Galileo, Fundação Zoobotânica do Rio Grande do Sul, Porto Alegre, RS, Brazil, for the information on the correct authorship and date of publication of the diving coleopteran species M. glauca; and to Samantha A. Seixas, Luiz Carlos Campos Daudt, and Cassandra de M. Monteiro for their constant help in the laboratory.

\section{REFERENCES}

Amato, J.F.R. \& S.B. Амато. 2005. New species of Temnocephala Blanchard (Platyhelminthes, Temnocephalida) ectosymbiont on giant water bugs, Belostoma spp. (Hemiptera, Belostomatidae) from southern Brazil. Revista Brasileira de Zoologia, Curitiba, 22 (1): 107-118.

BeLtzer, A.H. 1995. Biología alimentaria del pirincho Guira guira (Aves: Cuculidae) en el valle alluvial del Río Paraná medio, Argentina. Revista de Ecología Latinoamericana, Mérida, 2 (1-3): 13-18.

Dhanumkumari, C. \& R. Madhavi. 1983. Metacercaria of Stomylotrema sp. (Trematoda, Stomylotrematidae) from aquatic 
insects of Kondakarla Lake. Proceedings of the Indian Academy of Parasitology, Lucknow, 4: 83-85.

de Villalobos, L.C.; N.B. Camino \& P. Pérez-Goodwyn. 1998. Primera cita de Phreatomermis sp. (Nematoda, Mermithidae) parasitando a Belostoma elegans (Heteroptera, Belostomatidae). Revista de la Sociedad Entomológica Argentina, La Plata, 57: 56.

Digiani, M.C. 2002. Belostomatidae (Insecta: Heteroptera) as intermediate hosts of digenetic trematodes. Comparative Parasitology, Lawrence, 69 (1): 89-92.

Moretto, H.J.A. 1978. Presencia de Temnocephala (Temnocephalida, Platyhelminthes) em hemípteros acuáticos. Ciencia e
Investigación, Buenos Aires, 34: 95-99.

Ostrowski De NúÑEz, M. 1978. Zum Entwicklungszyklus von Stomylotrema vicarium. Angewandte Parasitologie, Jena, 19: 208-213.

ShyAmANDUSARI, K. \& K.H. RAO. 1998. Parasitocoenoses of the pond heron Ardeola grayi (Sykes) and the cattle egret Bubulcus íbis coromandus as functions of habitats and habits. Rivista di Parassitologia, Rome, 15: 225-234.

Vianna, G.J.C. \& A.L. De Melo. 2002. Aquatic Heteroptera as host of Temnocephala Blanchard (Platyhelminthes: Temnocephalidae) in Minas Gerais, Brazil. Lundiana, Belo Horizonte, 3: 151-153.

Received in 24.V.2005; accepted in 22.II.2006. 